\title{
COMMERCIAL PRINTS AND LABELS: A HYBRID IN COPYRIGHT LAW
}

\author{
BY WALTER J. DERENBERG*
}

BUSINESSMEN and others seeking protection for their industrial or artistic emblems and designs often fall into the error of talking loosely about "patenting a trade-mark" or "copyrighting a name" without having a clear conception of the fundamental legal distinctions between these statutory grants and their different practical applications.

These are not mere errors of language. To some extent they reflect a confusion in practice. It is for the legislature and the legal profession to clarify the matter in the minds of those for whose benefit the laws protecting industrial and artistic property were enacted. The past administration of trade-marks, copyrights and design patents in the United States has unfortunately done much to increase rather than diminish the prevailing confusion. This is particularly true of the protection and registrability of commercial prints and labels, which have always been treated as hybrids in our copyright system. It is paradoxical that, until this year, commercial prints and labels have simultaneotsly been considered worthy of copyright protection but undeserving of administration and registration by the Copyright Office at the Library of Congress. ${ }^{1}$ Some bewilderment has been caused by the fact that a commercial print or label could be registered by the Trade-Mark Division of the Patent Office without being afforded trade-mark protection, and be treated as "copyrighted" although lacking most of the literary or artistic merits of other copyrightable works. In order to cope with this situation, a law was passed on July 31, 1939 whose sole purpose was "to transfer jurisdiction over commercial prints and labels, for the purpose of copyright registration, to the Register of Copyrights." 2 The Act takes effect on July 1, 1940. ${ }^{3}$

*Lecturer in Law, New York University School of Law.

1. The discussion of labels and prints in 18 C. J. S. 176 begins with the following startling definition:

"Prints or labels to be used for any other article of manufacture are not copyrightable, although they may be registered in the patent office and receive protection as a copyrighted article ..."

2. Pub. L. 153, c. 396, 76th Cong., 1st Sess. (1939).

3. Section 3 of the new Act provides in part as follows:

"That commencing July 1, 1940, the Register of Copyrights is charged with the registration of claims to copyright properly presented, in all prints and labels published in connection with the sale or advertisement of articles of merchandise, including all claims to copyright in prints and labels pending in the Patent Office and uncleared at the close of business June 30, 1940. . . There shall be paid for registering a claim of copyright in any such 
It is the purpose of this Article to determine the extent to which this shift of jurisdiction and change in administration will contribute to the ultimate establishment of a more definite legal status for these heterogeneous creatures.

\section{The Creation of the Hybrid}

The hybrid nature of prints and labels was first given statutory recognition by the so-called "Print and Label Law" of 1874." From the passage of the first copyright Act in 1790, ${ }^{5}$ until 1870, a person desiring to secure copyright protection had to deposit the title of his book or other work with the Clerk of the United States District Court for his district; after 1831, a copy of the work itself had to be deposited with the clerl: It was the latter's duty to transmit the works thus deposited to the Secretary of State "to be preserved in his office." As the Patent Office was at that time in the State Department, the deposited works were kept there. In 1859 an Act of Congress transferred all matters relating to copyrights to the Department of the Interior. The Secretary of the Interior, in turn, delegated the administration of copyrights to the Commissioner of Patents. The Patent Office thereupon commenced a Register of Copyrights, and a "Librarian of Copyrights" was appointed. However, the deposit of the books or other copyrighted works in the various district courts still continued, and the only fee required was paid to the clerlof the court. Inadequate Patent Office facilities and lack of funds for a proper preservation of all the deposited copyrighted material led to a chaotic situation and to the loss of much irreplaceable material. ${ }^{7}$ A law was enacted in 1870 which vested the Library of Congress with authority and jurisdiction to administer the Copyright Law and to receive two copies of every work deposited in connection with an application. ${ }^{8}$

The Act of 1870 enumerated as proper objects of copyright protection "historical or other prints," as well as "prints and engravings and cuts." There was, however, no provision for the registration of commercial prints and labels apart from creations in the fine arts. An amendment,

print or label not a trade-mark $\$ 6$, which sum shall cover the expense of furnishing a certificate of such registration, under the seal of the Conyright Office, to the claimant of copyright."

Under $\$ 4$ of the new Act, copyrights for prints and labels registered in the TradeMark Division of the Patent Office prior to July 1,1940, shall be subject to renewal on behalf of the proprietor, upon application made to the Register of Copyrights within one year prior to the expiration of the registration term of 28 years.

4. 18 Stat. 79 (1874), 17 U. S. C. $\$ 63$ (1934).

5. 1 Stat. 124 (1790).

6. For a full description of this early history see Federico, Copyrights in the Patchl Office (1939) 21 I. PAT. OfF. Soc. 911.

7. See reports of Commissioners Holloway and Fisher to Congress in 1862 and 1869, reprinted in part in Federico, supra note 6, at 915, 916.

S. Rev. Stat. $\$ 4948$ (1875). 
known ever since as the "Print and Label Law," was passed on June 18, 1874 to fill the obvious need for their protection. The entire Print and Label Law is contained in Section 3 of the Act of 1874 which provides :

"That in the construction of this act the words 'engraving,' 'cut' and 'print' shall be applied only to pictorial illustrations or works connected with the fine arts, and no prints or labels designed to be used for any other articles of manufacture shall be entercd under the copyright lawe, but may be registered in the Patent Office. And the Commissioner of Patents is hereby charged with the supervision and control of the entry or registry of such prints or labels, in conformity with the regulations provided by lawe as to copyright of prints, except that there shall be paid for recording the title of any print or label, not a trade-mark, six dollars, which shall cover the expense of furnishing a copy of the record under the seal of the Commissioner of Patents, to the party entering the same." [Italics supplied].

When the present Copyright Act was passed on March 4, 1909, ${ }^{10}$ the Patent Office, acting under the impression that the repealing provisions of the Act also embraced the Print and Label Law, discontinued the registration of prints and labels. But the Attorney General, in a much debated opinion of December 22, 1909,11 concluded that the Print and Label Law had not been repealed by the Copyright Act of 1909. It has thus remained in effect up to the present time and will, with only one minor change in its wording, ${ }^{12}$ continue to be administered in the future by the Copyright Office.

A superficial glance at the wording of the Print and Label Law immediately shows the hybrid nature of the objects which it sought to protect. At the time of the law's enactment, the opinion apparently prevailed that the Library of Congress, as custodian of all copyrighted works,

9. A glance through the existing literature in the field of industrial and litcrary property reveals that in textbooks and law reviews the Print and Label Law has been neglected. The only comprehensive article is Symons, Copyright of Prints and Labcls (1933) 15 J. Pat. OfF. Soc. 162; see also Howell, The Print and Labcl Law (1922) 70 U. of Pa. L. Rev. 95 ; Amdur, Copyright Law and Practice (1936) 165; 2 Ladas, Tue International Protection of Literary and Artistic Property (1938) 728; Frceland. Copyright Protection of Advertising (1939) 27 Kx. L. J. 391; Carter, Print and Labcl Registration (1924) 6 J. PAT. OFF. Soc. 522. The Patent Office has issued the statutes and rules concerning the registration of prints and labels in pamphlet form and a separate pamphlet on General Inforaration about Protection of Trade-Marks, Prints and LABELS, all of which will probably be revised and re-issued by the Copyright Office after July 1,1940 , the effective date of the new law.

10. 35 Stat. 1075 (1909), 17 U. S. C. \& 1 (1934).

11. 28 Ops. Atr'y Gen. 116 (1909), reprinted in Copyright Decisions (1909-14) 240. Compare the interesting criticism in WeIL, AmericnN Copyright Lnw (1917) 222.

12. Infra p. 1224. 
was too dignified and scientific an institution to concern itself with the deposit of labels and prints used for commercial purposes. This attitude is revealed by an incidental remark made by the present Commissioner of Patents before the Temporary National Economic Committee during the hearings on revision of the patent laws. When asked about the Patent Office's administration of the Print and Label Law and its eventual transfer to the Copyright Office, the Commissioner replied:

"There is a very interesting story back of that, Senator. Years ago the Library of Congress, the Copyright Division, seemed to have very lofty ideas about such matters. They did not like to have in their office anything as practical and vulgar as a label for a tomato can, so they sent that all over to the Patent Office, and now there seems to be a change and they want to get that back." 13

Here lies the explanation why this proverbial tomato can label and other prints and labels "designed to be used for any other article of manufacture". were to be registered by the Trade-Mark Division of the Patent Office - not in accordance with well established principles of trade-mark law, but, as Section 3 expressly says, "in conformity with the regulations provided by law as to copyright of prints." MLoreover, Section 3 restricts the prints and labels eligible for registration to those "not a trade-mark." Although the terms "print" and "label" were at first used interchangeably by the Patent Office, Rules 28 and 29 concerning the registration of prints and labels now adopt the following definitions:

'28. The word 'print,' as used in section 3 of the copyright act, so far as it relates to registration in the Patent Office, is defined as an artistic and intellectual production designed to be used for an article of manufacture and in some fashion pertaining thereto, but not borne by it; such, for instance, as an advertisement thereof.

'29. The word 'label,' as used in this act, so far as it relates to registration in the Patent Office, is defined as an artistic and intellectual production impressed or stamped directly upon the article of manufacture or upon a slip or piece of paper or other material to be attached in any manner to manufactured articles or to bottles, boxes, and packages containing them, to indicate the article of manufacture." 14

It is apparent, from this definition alone, that a commercial label, so far as its purpose and effect are concerned, has many of the characteristics of a trade-mark, and that a registrant of such a label may be interested

13. 1 TNEC, Verbatim Recond of Proceenrwgs (1939) 434.

14. In the Patent Office pamphlet on general information concerning registration of prints and labels the public is advised that "A label must be attached to the goods, as by pasting onto the container, while a print cannot be attached to the goods, but must be used to advertise them, such as advertisements in magazines and street-ear cards." 
primarily in getting the label protected as a means of identification for his merchandise or business. He may deem this business device fully protected and the object of an exclusive right if he is advised that the label has been registered in the Trade-Mark Division of the Patent Office. If he inquires further into the nature of the protection which the registration grants, however, he will discover that the label is treated not like a trade-mark or business emblem but like a book or other work of literature and art. The early Patent Office decisions which, in the absence of an authoritative interpretation by any higher federal court, have become important precedents in this field, reflect this anomalous situation. Said the Commissioner:

"The purpose of the Label Law is believed to be to relegate to the Patent Office all registry in the general nature of, or akin to, copyright of things which were mere objects or appurtenances of articles of trade and to leave to the Library of Congress the registry of things whose value in exchange resides in themselves." 15

When, almost a quarter century later, the issue of the nature of the protection granted under the Print and Label Law was squarely raised in the courts, it was held in Fargo Mercantile Co. $v$. Brechet \& Richter $\mathrm{Co}^{10}$ that such labels, if properly registered, were entitled to as much protection as other copyrighted works even though they were mere "adjuncts of articles of trade." In that case, a label embodying as its principal feature a series of new and original recipes had been registered. The court conceded that the statute did not specifically define the status of a registered label. Plaintiff claimed that the label was entitled to the same protection as any other copyrighted work, whereas the defendant argued that a label "designed to be used for any other article of manufacture" could not become a copyrighted work through registration. In rejecting the defendant's theory the court concluded:

“. . . By the act of 1874 Congress did not intend to exclude from copyright protection 'prints or labels designed to be used for any other articles of manufacture,' provided such prints and labels met the test of being copyrightable matter. No such intention is indicated by anything that occurred in the passage of the act through Congress, and the mere provision contained in the act that such labels and prints should be registered in the Patent Office, instead of being filed with the Librarian of Congress, does not in our judgment lead to such a conclusion, especially in view of the further provision in the act that the Commissioner of Patents was charged with the supervision and control of the registry of such prints or labels 'in conformity with the regulations provided by law as to copyright prints.' This language zould indicate that the statutory

15. Ex parte Heinz Co., 62 O. G. Pat. Off. 1064 (C. P. 1892).

16. 295 Fed. 823 (C. C. A. Sth, 1924). 
provisions which conferred the protcctive right and which regulatcd the remedies were those relating to copyrights, not those relating either to trade-marks or to patcnts." 17 [Italics supplied].

In a subsequent case, Hoague-Sprague Corp. v. Meycr Co., the court, after showing little regard for the intrinsic value of a commercial label, held that it was a difference in administration rather than a difference in the nature of protection which distinguished commercial prints and labels from other copyrightable works. ${ }^{18}$ But a closer analysis will show that the problem cannot be solved by a mere shift of administrative jurisdiction from one office to another; more penetrating examination into the nature of these commercial utilities requires the recognition of three basic elements which will serve as clues to the legal classification of the print or label and its most appropriate mode of protection. For purposes of analysis, we shall call these elements:

(1) The artistic and literary ("copyright") elements;

(2) The commercial ("trade-mark") elements;

(3) The inventive ("design patent") elements.

A label, of course, may often be a combination of several of these elements. It is possible, too, that all three elements may be so perfectly represented in a single print or label as to warrant separate registration of each. But this situation is the exception rather than the rule. It is therefore usually necessary to determine which of these elements predominates. If this proves too difficult a task, inquiry should be made as to that aspect of the label which its owner desires most to protect, for copyright protection will not embrace the trade-mark or design elements and, conversely, protection of the latter will not cover any rights in the label's literary or artistic merits.

\section{The Artistic or Literary ("Copyright") Elearents of Prints and Labels}

Nothing can be copyrighted under Article I, Section $8(8)$ of the Federal Constitution unless it is a "writing" and unless it helps "promote the Progress of Science and useful Arts." It was long thought that "mere advertisements," in the form of a print or label or otherwise, did not qualify under this article. ${ }^{10}$ The United States Supreme Court stated in an early leading case, Higgins $v$. Keufol:

"To be entitled to a copyright the article must have by itself some value as a composition, at least to the extent of serving some

17. 295 Fed. 823,828 (C. C. A. Sth, 1924).

18. See 27 F. (2d) 176,180 (E. D. N. Y. 1928). The court said: "It would seem to make little difference in whose office in Washington the various commercial labels gather dust."

19. See Freeland, supra note 9 , at 393 , and cases there cited. 
purpose other than as a mere advertisement or designation of the subject to which it is attached." 20

However, in the now famous Bleistein case, Mr. Justice Holmes stated that an advertisement may be "promotive of the useful arts" and held that a circus poster of the usual type might be protected by the Copyright Law :

"The act, however construed, does not mean that ordinary posters are not good enough to be considered within its scope. The antithesis to 'illustrations or works connected with the fine arts' is not works of little merit or of humble degree, or illustrations addressed to the less educated classes; it is 'prints or labels designed to be used for any other articles of manufacture.' Certainly works are not the less connected with the fine arts because their pictorial quality attracts the crowd and therefore gives them a real use - if use means to increase trade and to help to make money. A picture is none the less a subject of copyright that it is used for an advertisement." 21

That Mr. Justice Holmes, in the above quoted statement, speals expressly of prints and labels for articles of manufacture as "the antithesis to illustrations or works connected with the fine arts" seems generally to have been disregarded. This statement might have been interpreted to mean that the Court would not pursue the liberal attitude, which it had now adopted toward the copyrightability of advertisements, in the case of commercial prints or labels. However, in the absence of any subsequent Supreme Court decision to the contrary, both the Patent Office and the courts, in determining the copyrightability of prints and labels, have followed the same general standard as that set up in the Blcistcin case. Under the influence of the Higgins case, the Commissioner said in Ex parte Palmer:

20. 140 U. S. 428,431 (1891).

21. Bleistein v. Donaldson Lith. Co., 188 U. S. 239 (1903). Some courts still scen u11aware of the importance of the Bleistein case when they refuse protection to labels or prints as "mere advertisements." A label was recently invalidated on this ground in Bobrecker v. Denebeim, 28 F. Supp. 383 (W. D. Mo. 1939). The court in that case obviously overlooked the fact that advertisements may qualify under the copyright statute. However, it found that the entire combination did not "bear the stem of originality" and in the absence of originality, a label, advertisement or any other work, would not be entitled to copyright protection. See, on the other hand, Deward \& Rich, Inc. v. Bristol Savings \& Loan Corp., 29 F. Supp. 777 (W. D. Va. 1939), where the court said:

"Since the decision of the Unitcd States Supreme Court in Bleistein v. Donaldson Lith. Co., I do not think it could be seriously urged that printed advertisements cannot be validly copyrighted. It is a matter of common knowledge that many of these advertisements in American publications of large circulation possess distinctive literary merit and real artistic originality. Other cases have approved the Bleistein case, and the general trend of modern cases, as I read them, seems clearly to be in the direction of extending and liberalizing the doctrine of the Bleistein case." 
"The conclusion to be drawn from this is that a label, in order to be entitled to registration under the Copyright Law in the Patent Office, needs to possess just as much artistic excellence, and no more, as would entitle it to copyright in the office of the Librarian of Congress." 22

In a subsequent case, Ex parte $H$ einz Co., the Commissioner stated:

"In any case some spark of intellectual creation must be present." 23

In the Fargo case which directly involved a registered label, the court, after quoting the Higgins and Bleistein cases, held that the fact that the label might be or was intended to be used for advertising purposes was not a bar to copyright, provided the label contained some original composition serving a useful purpose "apart from the mere advertisement of the article itself." It therefore seems well established, despite Mr. Justice Holmes' remark in the Bleistcin case, that a commercial print or label may be copyrighted even if it is a "mere advertisement" so long as there is present that "spark of intellectual creation" sought by the Patent Office in the Heinz case.

Neither the Copyright Statute nor the Print and Label Law offers any definition or measure of these minimum requirements. Said a recent writer :

"The Copyright Statute is about as useful to a lawyer confronted with the determination of the metes and bounds of copyrighting as a copy of Quia Emptores is to a modern conveyancer." 21

Mr. Justice Holmes declared in the Bleistcin case:

"It would be a dangerous undertaking for persons trained only to the law to constitute themselves final judges of the worth of pictorial illustrations outside of the narrowest and most obvious limits. ..."

The fact that a commercial label has been copyrighted or registered under the Print and Label Law does not even give rise to a presumption that the entire label or a component part thereof is original or has artistic merit. The provision in Section 3 of the Act of March 4, 1909 that "the copyright provided by this Act shall protect all the copyrightable component parts of the work" leaves to the courts the decision whether or not any of these parts are actually copyrightable. "What is registered is a claim to copyright.' . . . There is no provision for examination." ". ". . . The securing of a copyright is a purely mechanical matter involving the compliance with the statutes as to the filing of copies of the worls

22. 58 O. G. Pat. Off. 383 (C. P. 1892).

23. 62 O. G. Pat. Off. 1064 (C. P. 1892) (citing Ex farte Palmer, suspra note 22).

24. Umbreit, $A$ Consideration of Copyright (1939) 87 U. of P.. L. Rev. 932, 957.

25. $18 S$ U. S. 239,251 (1903).

26. Eggers v. Sun Sales Corp., 263 Fed. 373, 374 (C. C. A. 2d, 1920). 
for which copyright is sought. . . . It is then left to the courts . . . to define the zone in which the copyright owner is protected." 27 In determining the artistic (copyright) elements of commercial prints and labels, the Patent Office has followed the Copyright Office's practice in registering them as a matter of office routine independent of the copyrightability of their constituent parts ${ }^{28}$ - provided only that the applicant has met the "commercial" requirements described below.

The cases show that in order to qualify a print or label as a proper subject of copyright - i.e., as an "artistic creation" - according to the "General Instructions" issued by the Patent Office, no high degree of originality and artistic or literary merit is required. A bare minimum of originality and merit was sufficient in Ansehl v. Puritan Pharmaceuti$\mathrm{cal} \mathrm{Co}$. to render an advertisement copyrightable. ${ }^{20}$ After thoroughly reviewing all the cases decided to 1932, the court there held that material even of a "quasi-artistic character" might satisfy the test of originality. ${ }^{30}$ In order to be adjudged "original," the label's entire arrangement must bear witness to the registrant's own genius and personality, although the constituent parts of the label may be in the public domain. ${ }^{31}$ The court did not go into the still unsettled question whether the test of a work's "intrinsic merit" should be that of a certain minimum degree of "artistic or literary skill" or - as seems the more prevalent opinion 1934).

27. Sheldon v. Metro-Goldwyn Pictures Corp., 7 F. Supp. 837, 843 (S. D. N. Y.

28. See Ex parte Park \& Tilford, 4 T. M. Rep. 460 (1914) where the Examiner had refused registration of a label on the ground that it was not artistic. Said the Commissioner of Patents in reversing the Examiner:

"It has never been the practice to examine labels to determine their novelty or originality, so why should they be examined to determine their artistic merit. The office should not scrutinize labels too closely except to determine that they are to be attached to merchandise and are not of a nature to be registered by the Register of Copyright, rather than by the Commissioner of Patents. Since applicant's label is attached to merchandise, if in proper form, it should be registered in the Patent Office."

The Commissioner of Patents specifically held that the Higgins case did not require the Patent Office to examine the artistic merits of each label, but merely decided that, in the absence of originality and merit, the label would not be protected despite its registration.

29. 61 F. (2d) 131 (C. C. A. 8th, 1932), (1932) 46 HARv. L. Rev. 332, (1933) 27 ILl. L. REv. 827, (1933) 17 Mins. L. REv. 327.

30. The court quoted from WeIL, American Copyright Law (1917) 226 :

"It requires very little originality, indeed, to render proposed advertising matter copyrightable . . . The tendency of the more modern cases is to increase, rather than to restrict, the subject matter of copyright and this is plainly indicated by the advertisement cases."

31. "The originality required in case of copyright means little more than a prohibition of actual copying." Hoague-Sprague Corp. v. Meyer, 31 F. (2d) 583, 586 (E. D. N. Y. 1929). For further references on "originality," see AMDUR, op. cit. supra note 9, c. III, $\S \S 3$ and 4. 
today - that of "expenditure of intellectual labor," for the advertisement involved in the Ansehl case seemed to qualify under either test. ${ }^{32}$

No matter what test the courts finally apply, it is extremely important that businessmen and lawyers consider these "intrinsic merits" of the print or label as distinct from its strictly commercial elements. It should be part of the educational program of the Copyright Office, in taking over the administration of the registry of these marketing devices, to point out that much more than registration under the Print and Label Law is needed for proper protection of those business values which are linked up and associated with a print or label, and that precautions must be taken in this respect whether registration be in the Patent Office or, as henceforth, in the Library of Congress. The fact should generally be made known that, notwithstanding the widespread contrary belief in the business world, copyright registration of a commercial print or label fails to protect the registrant in any of the following respects:

1. It does not, as indicated, create even a presumption that the entire label or the component parts thereof meet the minimum requirements of originality and intrinsic merit necessary for true copyright protection.

2. If the print or label embodies a new business idea or a new advertising idea, the idea as such is not protected by the copyright. Notwithstanding an isolated recent challenge, ${ }^{33}$ it is an established principle of copyright law that the statute does not protect an idea as such, but the form in which it is expressed. ${ }^{34}$ As was said in one of the leading cases:

"... Ideas as such are not protected. . . . The copyright law

protects the means of expressing an idea; . . . if the same idea can be expressed in a plurality of totally different manners, a plurality of copyrights may result and no infringement will exist."3s

Registration of the print or label, therefore, will not give the registrant an exclusive right in a new or unique advertising idea which has for the first time found expression in the label or print.

32. For the "expenditure of labor" theory, see Jeweler's Circular Pub. Co.v. Keystone Pub. Co., 281 Fed. 83, \&8 (C. C. A. 2d, 1922), stating that "3 man who goes through the streets of a town and puts down the names of each of the inhabitants, with their occupations and their street number, acquires material of which he is the author. He produces by his labor a meritorious composition, in which he may obtain a copyright. . . " For discussion of the various theories, see Fahey, The Scope of Copyright Protction (1939)

$28 \mathrm{KY}$. L. J. 18; Axnur, op. cit. supra note 9, c. III.

33. UXIBRETT, loc. cit. sipra note 24.

34. See Comment (1939) 10 AIR L. Rev. 394; Schweitzer, Restatement of Proferly Rights isz Ideas (1938) 72 U. S. L. REv. 439.

35. Dymow v. Bolton, 11 F. (2d) 690,691 (C. C. A. 2d, 1926); accord, Ansehl v. Puritan Pharm. Co., 61 F. (2d) 131 (C.C. A. 8th, 1932) and cases there cited. The Supreme Court intimated in White-Smith Music Pub. Co. v. Apollo Co., 209 U. S. 1, 17 (1907), that the copyright statute does not provide for the protection "of the intellectual conception" apart from the tangible thing produced, "however meritorious such conception may be" 
3. If the print or label contains a word or picture which is intended to serve as the registrant's trade-mark and which could perform that function if it were appropriated as a trade-mark by the registrant at some subsequent time, no exclusive rights in such a name or mark are acquired by copyrighting the label. If the mark is not actually used on the goods in a trade-mark sense, the registrant cannot obtain any common law trade-mark rights therein by simply making it part of a label or print. ${ }^{30}$ An interloper, therefore, could not be prevented from appropriating such a name - indeed, he could acquire a valid common law title to the mark by making a proper trade-mark use thereof. ${ }^{37}$ Moreover, it is settled law that, in any dispute between two claimants to a trade-mark, prior registration of the mark applied for in a print or label is, in itself, insufficient evidence to establish a date of first use. As was said by the Commissioner of Patents :

"The registration of a label is not by any statute made primn facie evidence of ownership of the mark shown thereon, nor even evidence that the mark shown on the label was used as a trademark. The registration of a trade-mark is by statute made prima facie evidence of ownership." ${ }^{38}$

In one trade-mark interference proceeding, the junior party moved to shift the burden of proof in view of his registration of a label showing the mark in question prior to the date claimed by the senior party. It was contended that Section 55 of the Copyright Act permits admission of the registration certificate "as prima facie evidence of the facts stated therein." The Commissioner of Patents refused, however, to give such effect to the certificate on the significant ground that the registration of a label "raises no presumption of use in interstate commerce of the traclemark appearing thereon as of any particular date. The label may have applied to the goods long prior to any sale in interstate commerce." 30

Registration of a label or print therefore has no evidentiary value either as to the validity of a word or picture used thereon as a trademark, or as to the alleged date of first use of the mark.

4. Registration of the print or label grants no exclusive right in any descriptive language or in trade slogans which are parts of the print or label. ${ }^{39}$ The usual trade or advertising slogans are not now protected

36. That a trade-mark as such cannot be copyrighted has been accepted doctrinc ever since the Supreme Court decided in the Trade-Mark Cases, 100 U. S. 82 (1879) that a trade- mark is not "a writing" and not "the fruit of intellectual labor."

37. On the question of what constitutes a proper trade-mark use and how to accuirc trade-mark rights, see Derenberg, Trade-Mark Protection and Unfair Trading (1936) 503.

38. Colby \& McDermott v. The Max Glick Co., 16 T. M. Rep. 195 (C. P. 1925).

39. Lummis \& Co. v. West Indies Limes Co., 16 T. M. Rep. 362 (C. P. 1922).

39a. Compare Copyright Office Explanatory Circular No. 19c.:

"Mere clauses or expressions, standing alone, are not in themselves copyrightable, and do not become so simply because they constitute or lend 
either by the Copyright Law or the Trade-Mark Law, and will not be protected by the courts unless the circumstances of infringement spell out a cause of action for unfair competition. The only other attempts to protect slogans have been slogan clearing houses privately established by various trade associations. ${ }^{40}$ The legal protection granted a slogan appearing as part of a registered print or label is no greater than the legal effect of its deposit with Printers' Ink or with the United States Trade-Mark Association. If, however, a "substantial part" of the copyrighted label or print consists not merely of "trade puff" or slang expressions which belong to the public domain, but of a "meritorious composition" of literary or artistic value coming within the purview of the above-mentioned "expenditure of labor" theory, this literary material would be copyrightable whether it appears as part of a print or label or in another form. Thus the court in the Fargo case held that a series of new and original recipes embodied in a registered label was a valid subject for copyright.

5. The test of infringement of a registered print or label has sometimes been thought to be identical with the criterion for trade-mark infringement, i.e., confusing similarity of the two labels. Indeed, at least one court has actually applied this "confusion" test."1 It is clear, however, that confusion in trade is not the test for anything protected under the Copyright Law and that copyright infringement exists only where there

themselves to a play upon words. Hence certain advertising announcements, slogans, mottoes, catch words, or the like, falling within the above classification, are not as a rule subject to registration by this Office.

"Where such words or phrases constitute an element of trade-marlis or other identifying devices, they may sometimes be protected by general rules of law against unfair competition, but the Copyright Office has nothing to do with such protection."

40. Thus the United States Trade-Mark Association has for many years registered trade slogans for its members and publishcd them regularly in its Bulletin. Lilsewise, Printers' INK in 1919 inaugurated a Clearing House of advertising phrases as a repository against which advertisers and agencies could check the originality of slogans they contemplated using. With regard to this service Printers' Ink states:

'For its non-official custodianship, Printers' INk, of course, makes no charge. Neither does it make any bones about affording legal protection. It doesn't-it simply offers an easy recourse for those who would find out whether a certain phrase has ever been used hefore"

41. See Wm. Faehndrich, Inc. v. Wheeler Riddle Chrese Co., Inc., 34 F. (2d) 43, 44 (E. D. N. Y. 1929) :

"As I have before stated, the evidence does not convince me that confusion was caused in the trade by any similarity in the defendant's label with that of the plaintiff.

"I do not find any confusing similarity in the label of the defendant with that of the plaintiff, and therefore, it does not infringe." 
is evidence of "copying" or "plagiarism" of a "substantial part" of the copyrighted work. ${ }^{42}$

\section{The Commercial (Trade-Mark) Elements of Prints and Lablis}

It has been shown that, in registering commercial prints and labels, the Trade-Mark Division of the Patent Office did not, nor will the Copyright Office, after July 1st under the new law, determine any question of "artistic merit" or "originality." The Trade-Mark Division has, however, built up a respectable body of precedents for determining those components of commercial prints and labels which we have designated as "trade-mark" elements. The Patent Office has here guided itself, wherever possible, by those principles which are followed in the registration of trade-marks. ${ }^{43}$ Inasmuch as the Act of July 31, 1939 merely transfers jurisdiction over the registration of prints and labels to the Copyright Office, but does not change the wording or contents of the old Print and Label Law, ${ }^{44}$ there immediately arises the question of the extent to which the Copyright Office will apply the technical rules for registry of commercial prints and labels which the Patent Office has established.

What have been these commercial prerequisites for the registration of a print or label? ${ }^{45}$

1. The label must be "affixed" to an "article of manufacture." Section 3 of the Act of July 31, 1939 requires that the label be used in connection with the sale or advertisement of "an article of merchandise." This change from "article of manufacture" to "article of merchandise" is the only change in the substantive law governing prints and labels. But

42. Copying of a name or mark cannot by itself be a sufficient basis for a finding of "copyright infringement" for such a doctrine would logically lead to a gradual elimination of trade-mark registration. If a registrant, by including a mark in a registered label, were thereby able to hold an imitator liable in copyright infringement-and subject to the triple damage provision of the Copyright Act!-the registrant could acquire a practical monopoly in a name which would be far superior to a trade-mark right. Use of the name on entirely unrelated goods, although permissible under $\$ 5$ of the Trade-Mark Act, might nevertheless be "copyright infringement;" a mark long abandoned as a trade-mark might survive the discontinuance of the business and its good will and live a shatclow existence for 28-or, if renewed, 56-years as a copyrighted label. The Trade-Mark Cases, 100 U. S. 82 (1879) clearly indicate that the imitation of a name or mark alone falls within the realm of trade-mark infringement or passing off rather than of copyright infringement.

43. Compare Symons, Copyright of Prints and Labels (1933) 15 J. PAT. OrF. Soc. 162,173 et seq. and cases there cited.

44. See, however, the change in language mentioned in the next paragraph.

45. In the following pages, a commercial label will be used for illustration, but cverything that will be said applies equally to registration of a print, the only difference being that the print is not attached to the goods, but used in some other form to advertise them. 
even in its amended form this section greatly reduces the number of registrable labels, particularly if the narrow rules concerning affixation and registrability which govern in trade-mark cases ${ }^{26}$ are applied. No label, despite its possible artistic merit, can be copyrighted unless it is physically attached to an article of merchandise. This limitation has led the Patent Office to reject many commercial labels. A print for a laundry service, for example, has been refused registration on the ground that such service was not an article of manufacture. ${ }^{47}$ In $E_{x}$ parte Le Page, it was held that a picture of two female heads facing each other, in conjunction with certain words, was not registrable as a print because it was to be used in connection with permanent waves which were not deemed an "article of manufacture." The Commissioner said:

"So far as appears in the record, a permanent wave of a woman's hair in its growing state has never been regarded as a vendible commodity." 48

For the same reason, it was held in Ex parte Lee Mercantile Co. ${ }^{48}$ that a print which bore the notation "high-grade food stores, united for service, quality and economy," was not registrable.

"A distinction should be observed as between words which are descriptive of stores and those which are descriptive of the articles of commerce sold by the stores." 19

Very recently the Commissioner held that a print which admittedly referred to a process rather than to an article, and was descriptive thereof, was not registrable because "a process" was not an article of manufacture. ${ }^{50}$ In Ex parte Apex Electrical IIfg. Co., ${ }^{51}$ the Commissioner rejected an application to register a print consisting of a picture of an hour-glass on which was printed "A woman's time - how much is it worth?" on the grounds that the merchandise in question was not an hour-glass, and that the print was not properly descriptive of any other article. Ex parte Frost was a case in which an application was made to register a print for an insurance business. The application failed because insurance "is not an article of manufacture." 52 It seems evident that the change from "manufacture" to "merchandise" will not lead to a different result in any of these situations.

2. Nor does the Act of July 31, 1939 contain any modification of the hard and fast rule developed by the Trade-Mark Division of the Patent Office that no print or label can be copyrighted unless it is properly

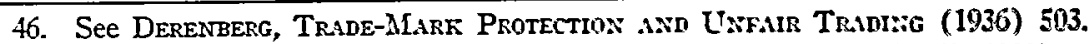

47. Ex parte Kinks L. Parish Laundry Corp., 20 T. MI. Rep. 162 (C. P. 1929).

48. 21 T. M. Rep. 222 (C. P. 1931).

49. 21 T. M. Rep. 641 (C. P. 1931).

50. Ex parte Westinghouse Electric \& MIfg. Co., 41 U. S. P. Q. 112 (C. P. 1939).

51. 15 T. M. Rep. 124 (C. P. 1924).

52. 15 T. MI. Rep. 332 (C. P. 1925). 
descriptive of the article of merchandise in connection with which it is used. Thus, while descriptiveness is an insurmountable barrier to registration of a trade-mark, ${ }^{53}$ it has been made a prerequisite to the registration of a label or print, even in the absence of any such limitation in the statute itself. Rule 30 of the Patent Office provides:

"No print or label can be registered unless it properly belongs to an article of manufacture and is descriptive thereof."

Two reasons suggest themselves as the basis of the Patent Office's establishment of such a rule: (1) it helps to provide a convenient distinction between a label and a trade-mark; and (2) it serves to give prominence to the commercial aspects and functions of the label. The result has been that a commercial print or label, no matter how artistic, cannot be copyrighted as such if it fails properly to describe the article. Some random illustrations will reveal how this rule has affected the administration of the Print and Label Law.

An advertisement of an exposition, inviting building material and home equipment manufacturers to exhibit their products, was refused registration on the ground that it did not "describe" any goods.

"Inspection of the print shows that it is not descriptive of anything, unless it is of the exposition itself. It certainly in no way describes building material." 54

A print for machines for vending ice, which contained an elliptical background with the word "ICE" in large letters and the word "SERV" in script across it, was held registrable on the grounds that a fair reading of the print would be "SERV ICE" and that, therefore, the label was sufficiently descriptive of the machines. ${ }^{55}$ In denying registration to a label for a device protecting garments from moths, which pictured a carton completely unfolded and a design indicating that if the carton were folded to its intended position, it possessed certain characteristics of a wooden container, the Commissioner said :

". . . it would appear clear enough that the design does not function as a label, as it in no way indicates or describes the goods, but merely simulates or is an imitation of a complete wooden box." 50

53. Section 5 of the Federal Trade-Mark Act of 1905, 33 SrAT. 724 (1905), 15 U. S. C. $\$ 86$ (1934), provides:

"No mark by which the goods of the owner of the mark may be distinguished from other goods of the same class shall be refuscd registration as a trade-mark on account of the nature of such mark unless such mark . . . consists merely in words or devices zehich are descriptive of the goods with which they are used or of the character or quality of such goods." [Italics supplied].

54. Ex parte Own Your Own Home Exposition, Inc., 15 T. M. Rep. 430 (C. P. 1925).

55. Ex parte Central Ice and Cold Storage Co., 22 T. M. Rep. 38 (C. P. 1932).

56. Ex parte The Expello Corp., 23 T. M. Rep. 541 (C. P. 1933). 
Again, in the case of a label for mailing envelopes, which consisted of the representation of an aeroplane flying over a city skyline, it was held that such representation "failed properly to describe the article of manufacture, namely, an envelope." 57

Adding further restrictions to this self-imposed requirement of descriptiveness for prints and labels, the Patent Office has held that the mere use of a trademark in the label is an insufficient description, even though the particular trade-mark may be widely known in the business world. The strange result has sometimes been reached whereby a well-known trade-mark, whose primary commercial function was to identify the goods of a particular manufacturer, has been viewed as insufficiently descriptive to comply with the Print and Label Law. The leading case on this point involved a print displaying a pair of clasped hands, above which were the words "perfect partners" and below which were the words "pennzip, pennzoil." It was claimed that, because "pennzip" was registered as a trade-mark for gasoline and "pennzoil" for motor oil, these words were sufficiently descriptive of the products named. It was further alleged - and this seems to be the only instance in which the validity of Rule 30 has ever been challenged - that the Patent Office was going beyond any provision of the Copyright Act in requiring that a print or label must be descriptive. In rejecting this argument, the Commissioner said:

"It is true that the Act does not expressly contain such a requirement, but it is also true that the Rule violates no provision of the statute, nor does it appear to be unreasonable. It has been in effect for a great many years and has been accepted and relied upon by industry and the legal profession. If, at this late date, applicants seriously question its validity, I think recourse should be had to the courts rather than to the Commissioner of Patents." "ss

57. Ex parte The Gray Envelope Mfg. Co., 24 T. M. Rep. 89 (C. P. 1934). The language in the opinion is typical of the attitude of the Patent Office:

"If the label were used upon, for example, toy aeroplanes, it would undoubtedly be descriptive and, if all other requirements were met, it would probably be registrable. However, when used unon envelones, the label is not descriptive of the goods claimed."

The Patent Office has also held the following label ten be unregistrable- "Firestone high speed type, $4 \mathrm{ply}, 5-50-17$, for flat base or American drop center rim made in the U. S. A." - on the ground that the words "high speed type" and "4 ply" were not sufficiently descriptive of tires. Ex parte The Firestone Tire \& Rubber Co., 27 T. M. Rep. 408 (C. P. 1936).

58. Ex parte Pennzoil Co., 27 T. M. Rep. 660 (C. P. 1937). The Commissiuner indicated that a different rule might apply where the trade-mark has treome so widely known that it signifies the article itself rather than the manufacturer. "Coca-Cola" and "Kodak" were cited as illustrations. As both these names are still valid trade-marl:s, it is difficult to find any legal distinction between the use of those names in a label and the use of some less widely known mark. 
He thus conceded not only that the Print and Label Law is itself silent on the requirement of descriptiveness, but that evidently no logical or legal ground for this requirement could be found other than the mere fact that the Patent Office has always followed this self-imposed rule. ${ }^{\text {t0 }}$ There is no reason why the Copyright Office, in taking over jurisdiction in July 1940, should adhere to Rule 30 - a regulation which originated in an attempt made some fifty years ago to find valid distinctions between commercial labels and trade-marks.

3. Another limitation which the Patent Office has read into the Print and Label Law is that it will not register a label which is contrary to public policy. Although Section 5 of the Federal Trade-Mark Act of 1905 prohibits the registration of scandalous or immoral trade-marks, the Law nowhere contains a general prohibition of marks whose registration would be against public policy. On this latter ground, however, a label containing the words "King Edward VII" was denied registration."

4. In a very recent case, ${ }^{01}$ registration of a label was refused as "scandalous" even though the Copyright Law, contrary to the Trade-Mark Act, contains no prohibition against scandalous labels. Although there was admittedly no statutory authority for such a refusal, the Commissioner of Patents followed a recent decision of the Court of Customs and Patent Appeals in which the court had refused to register the word "Madonna" as a trade-mark for wine on the ground that "a pictorial representation of the Virgin Mary as a trade-mark for wines would be shocking to the sense of propriety or call out condemnation." 62

5. Conversely, a few of the restrictive provisions found in the TradeMark Act of 1905 have recently been held inapplicable to print and label cases. The most important of these provisions, prohibiting registration of the name of a living individual without his written consent, may be and has been ignored. It was alleged in a recent case that the picturcs of two unidentified men appeared on the print and that registration should be refused because of the absence of their written consent. In distinguishing the "King Edward" case as based upon general principles of public policy rather than upon the statutory prohibition against registration of an individual's name, the Commissioner pointed out that neither common

59. Even the Patent Office has occasionally departed from its rule that the described merchandise must be specifically named. In an early case involving a label containing the words "Finest American manufacture-handmade" surrounding a colored field on which appeared the picture of a Belgian hare and the words "Belgian hare felt-extra quality," it was held that these words sufficiently described the merchandise involved, namely, hats. "To comply with the requirements that a label must describe the goods, it is not necessary that the label should specifically name the article to which it is attached." Ex partc Danbury Hat Co., 6 T. M. Rep. 242 (C. P. 1916).

60. Ex parte Dewar \& Sons, Ltd., 98 O. G. Pat. Off. 1037 (C. P. 1902).

61. Ex parte F. \& M. Importing Co., 39 U. S. P. Q. 451 (C. P. 1938).

62. In re Riverbank Canning Co., 95 F. (2d) 327 (C. C. P. A. 1938). 
law principles concerning the right of privacy nor Section 5 of the Federal Trade-Mark Act prevented the registration of a print on this ground. In refusing to apply trade-mark law, the Commissioner said:

"The Examiner suggests that the statutory prohibition against registration of the portrait of a living person as a trade-mark, should, by analogy, be applied also to prints and labels. I cannot adopt this suggestion. The task of copyrighting writings has been divided between the Copyright Division of the Library of Congress and the Patent Office. Inquiry discloses that the Copyright Division is disposed to permit copyright of photographs without the consent of persons appearing in them. In the interests of uniformity the Patent Office must conform to established practice within the Copyright Division of the Library of Congress."

6. In a still more recent case, the Commissioner allowed registration of a label including the words "U.S.A." on the ground that the prohibition against registration of a trade-mark including the insignia of the United States does not apply to the registration of a label.

7. Apart from, and in addition to, all these commercial restrictions, there is one final limitation suggested by the wording of the Print and Label Law itself, which is also found in the amendment of July 31, 1939. The Law in terms applies only to prints and labels "not a trade-mark." This has been construed to mean that no label which, considered as a whole, is a trade-mark rather than a label may be registered under the provisions of this Act. Here, then, is still another pitfall for the applicant. In one of the early leading cases, it was held that a label bearing all characteristics of a composite trade-mark could not be registered as a label, even though the applicant called it a label and tried to register it under the Print and Label Act. ${ }^{65}$ After stating that trade-marks and labels are so intimately connected that confusion might arise if they were supervised by separate and independent officials, the Commissioner held:

"Something which is the subject matter of a trade-mark under every known definition does not have the requirements of a label if not used as a trade-mark. It is not a matter of the applicant's preference." 66

63. Ex parte A C Spark Plug Co., 25 U. S. P. Q. 75 (C. P. 1935).

64. Ex parte H. A. Loeb \& Co., 41 U. S. P. Q. 410 (C. P. 1939). For further references and illustrations see Symons, Copyright of Prists and Lalels (1933) 15 J. PAT. OFF. Soc. 162, 173 et seq. The cases cited by Symons concerning use of public insignia must be considered overruled by the Locb case. In Ex parte Allen \& Co., 156 O. G. Pat. Off. 1065 (C. P. 1910), registration of a print was refused on the ground that it was a device to further a lottery or game of chance.

65. Ex parte Moodie, 28 O. G. Pat. Off. 1271 (C. P. 1SS4).

66. Accord, Mfatter of Palmer, 58 O. G. Pat. Off. 383 (C. P. 1892). 
$\mathrm{He}$ also stated emphatically that the Patent Office would not blindly accept the applicant's denomination of the work as a trade-mark or label.

On the other hand, it is no obstacle to the copyrightability of a print or label that a trade-mark is found in its context, if that trade-mark is but a part of the general combination - the restriction above applies only where the trade-mark is the sole artistic feature of the label. ${ }^{67}$ In Ex parte Wahrmann ${ }^{68}$ an attempt was made to register as a label a picture of a bank building marked "trade-mark." Registration as a label was permitted on the grounds that the rest of the label qualified sufficiently and that it was no bar to registration that one of the features thereof was used as a trade-mark and so marked on the label. The same view has been taken by the federal courts in the few cases in which this question has been presented. ${ }^{60}$

8. Finally, the registration of a print or label today must meet the requirements of certain special laws, such as the recent Food and Drug Act, ${ }^{70}$ or the label requirements of the Federal Alcohol Commission. ${ }^{71}$

\section{The Inventive ("Design") Elements of Prints and Labels}

All these "artistic" and "commercial" requirements multiply the hazards involved in selecting a print or label which is not only registrable, but will be granted protection by the courts as well. An unusual degree of attention and skill is needed, both on the part of the marketing expert and of the attorney, to create and introduce a label whose validity will stand up when tested by all these standards and rules. But that is not all. These prints and labels occasionally involve additional considerations. They may enter the realm of the Design Patent Law and be treated as designs rather than copyrights or trade-marks. This possibility is suggested not only by the close relationship between design patents and copyrights in general, but, more particularly, because of the well established rule of the Patent Office, universally applied under both the Trade-Mark Law and the Print and Label Law, ${ }^{72}$ that no print or label will be registered which constitutes an article of merchandise itself or utilitarian parts

67. Ex parte Wm. T. Reynolds \& Co., 108 O. G. Pat. Off. 559 (C. P. 1904).

68. 204 O. G. Pat. Off. 1345 (C. P. 1914).

69. See, for example, the Fargo case, 295 Fed. 823 (C. C. A. 8th, 1924) where the Court, after expressing doubt whether the copyright protection covered the "fanciful emblem" on the label, indicated that the emblem's presence "did not destroy the copyright protection" covering the recipes printed on the label.

70. 52 Stat. 1040, 21 U. S. C. $\$ 301$ (Supp. 1938); see symposium in (1939) 6 LAW \& Contemp. Prob. 1 et seq.

71. 49 Stat. 1965 (1935), 27 U. S. C. $\$ 205$ (e) (Supp. 1938).

72. See, in particular, Goodyear Tire \& Rubber Co. v. Robertson, 25 F. (2d) 833

(C. C. A. 4th, 1928); Derenberg, Trade-Mirk Protection and Unfair Trading (1936) 309 et seq. 
thereof. To illustrate: in 1929, an application was made to register a print advertising a tie-cleaning service. The print consisted of a diamondshaped outline enclosing the words "Did you ever have your ties cleaned - they come back with all their original respectability," to which was added a further statement of the cost of cleaning. In refusing registration, the Commissioner said:

"The fact that the statute confines the registration of prints and labels in the Patent Office to those designed to be used for 'any other articles of manufacture' seems conclusive that the print must be for some article of manufacture other than itself. The terms of the statute do not appear to support the view that the print itself may be the article of manufacture contemplated by the Act." 73

Following this rule, the Patent Office in 1930 rejected a print for the front cover of a calendar. ${ }^{74}$ Recently a print, claimed to be used for advertising purposes for theatrical programs, was rejected because the thing sought to be registered was, itself, a progran. ${ }^{\text {i5 }}$ Indeed, it was contended as late as 1924 in the Fargo case that all labels and prints to be used for an article of manufacture were not copyrighted but registered as "design patents." The argument was advanced that the strict regulations in regard to patents were inapplicable, and the more lenient provisions relating to copyrights substituted, only "because these labels differ so greatly from the ordinary invention in their intrinsic nature."70 Moreover, the first Design Patent Act of $1842,{ }^{77}$ as well as the other predecessor Acts to the present Act of May 9, 1902,78 expressly mentioned, inter alia, as subject-matter for design patents "any new and useful patent or print [Italics supplied] or picture to be either worked into or worked on, printed or painted . . . or otherwise fixed on any article of manufacture." Thus, for about thirty-five years a section in the Design Patent Law for "prints on articles of manufacture" has been in effect simultaneously with the Print and Label Law providing for registration of prints and labels "designed to be used on or in connection with an article of manufacture." The Attorney General clearly noticed this incongruity in the course of his opinion previously referred to, and tried to explain it away:

73. Ex parte Ervin Press Co.. 19 T. M. Rep. 40 (C. P. 1929).

74. "I know of no holding that, nor do I know of a logical reason why, applicant may pick out and separate a portion of the circular or the pamphlet and register that portion as a print. If that were permissible, an ornamental title page to any book could be so registered." Ex parte Earle Ray Thompsen, 20 T. MI. Rep. 497 (C. P. 1930); if. Ex parte The Gray Envelope Mrg. Co., 24 T. M. Rep. 80 (C. P. 1934).

75. Ex parte Frontenac Theatre, 27 T. Mr. Rep. 662 (C. P. 1936). The Commissioner said: "Calling a program a print does not necessarily make a print out of a program."

76. 295 Fed. $\$ 23, \$ 27$ (C. C. A. \$th, 1924).

77. 5 Stat. 543 (1S42); compare 1 WaLKer ON PAterts (Deller's ed. 1937) 212.

7S. 32 Stat. 193 (1902), 35 U. S. C. $\$ 73$ (1934). 
'It will thus be seen that the word 'print' was used in this Act in connection with both things which might be patented and also those subject to copyright, but the distinction between the two characters of prints was clearly drawn by the clause in said Section 71, which limited the prints that might be patented to those which were 'to be placed on or worked into any article of manufacture." "70 [Italics supplied].

It is not surprising, then, to find a federal judge deciding at an early date that, to be registrable, a print or label must also be patentable as a design. ${ }^{80}$ Not until the decision of the Fargo case in 1924 was it clearly recognized that a print or label, in order to be registered, need not meet the requirements of a design patent. But even today it is not always an easy task to determine whether a print or label should be protected as a design or "copyrighted" under the Print and Label Law. It must not be overlooked that the design patent, as we know it today, is almost as much a hybrid as a print or label. Professor Karl Fenning, in giving testimony before the House Committee on Patents on the question of design protection, stated:

"I have a feeling that while the design must be protected and should be protected the same as copyrights and patents are protected, probably the expedient thing to do is not to classify them either as a copyright or patent, but as a sort of hybrid between the two; as having some aspects of the one and some aspects of the other." 81

This is not the place to discuss the controversial nature of design patents. It will suffice to stress the fact that the present statute, in using the word "ornamental" and omitting the word "useful," brings the design patent much closer to the category of copyrights than to the class of mechanical patents. $^{82}$ Moreover, apart from being ornamental, a design under our present law must be "original" and must involve the exercise of some

79. 28 Ops. AtT'y GeN. 116 (1909).

80. Rosenbach v. Dreyfuss, 2 Fed. 217 (S. D. N. Y. 1880). Sce aiso Schumacher v. Wogram, 35 Fed. 210 (S. D. N. Y. 1888) (copyright of a picture under a label was held invalid as an evasion of the Print and Label Law).

81. Hearings on Design Protection before the Committee on Patents, $72 \mathrm{~d}$ Cong., 1 st Sess. (1932) 3.

82. To the same effect see Umbreit, $A$ Consideration of Copyright (1939) $87 \mathrm{U}$. of PA. L. REv. 932, 934, who ably demonstrates the erroneous classification of designs as "patents":

"As an abstract question, there would seem to be more similarity between a design patent and a copyright than there is between a design patent and a mechanical patent. The fact that the law of design patents is following the precedents of mechanical patents rather than of copyrights is an accident of administration. It is due to their name and to their subjection to the jurisdiction of the Patent Office." 
"inventive faculty." 83 The only conceivable reason why such designs are not registrable under the rules and regulations of the Copyright Office would seem to be that special statutory protection may be sought under the Design Patent Law. Any print or design which, upon being embodied in an article of manufacture ceases to be a mere drawing or picture, is no longer capable of copyright protection and comes within the scope of the Design Patent Act. Inasmuch as the Design Patent Law, contrary to the requirements of the Copyright Law, insists upon the presence of "invention" and "novelty," innumerable designs and prints are lost in the "no man's land" between copyright law and design patent law. On the other hand, many commercial designs may originally qualify under either the Design Patent or the Copyright Law, according to the owner's choice, as strikingly illustrated by the recent $U$ Inderkoffler case. . $^{\text {st }}$ It was there alleged that a design for a cemetery monument was not copyrightable as a design for a work of art, but should have been patented under the Design Patent Law as a design for an article of manufacture. After pointing out that the present Copyright Act omitted the word "fine" before the word "art" in connection with models and designs, the court reached this conclusion:

"A certain object may be an article of manufacture as well as a work of art and the design, therefore, might well come under the Design Patent Law as a design for an article of manufacture or under the Copyright Act as a design for a work of art." 85

83. See 1 Walker on Patents (Deller's ed. 1937) 419; In re Hall, 69 F. (2d) 660 (C. C. P. A. 1934). See also the recent cases of Battery Patents Corp. v. Coe, 93 F. (2d) 220 (App. D. C. 1937) ; Balmer Co. v. Bay Ridge Specy Co., 20 F. Supp. 714 (D. N. J. 1937) ; Pullman Coach Co. v. Futorian, 39 U. S. P. Q. 217 (N. D. III. 1938) ; Ainsworth v. Gill Glass \& Fixture Co., 26 F. Supp. 183 (E. D. Pa. 1938); In re Campbell, 42 U. S. P. Q. 12 (C. C. P. A. 1939); Viehmann v. D. F. H. Novelty Furn. Co., 27 F. Supp. 566 (E. D. N. Y. 1939) ; and, particularly, In re Torgerson, 104 F. (2d) 194 (C. C. P. A. 1939), where the court said:

"The statute which authorizes the granting of a design patent, $\$ 4929$ of the Revised Statutes ( 35 U. S. C. 73), requires that the design to be inventive must be new, original, and ornamental. $\$ 4893$ of the Revised Statutes ( 35 U. S. C. 36 ) requires that the invention be sufficiently tIseful ond inportant before the Commissioner is required to issue a patent therefor. [Italics supplied].

"Every new design of an article of manufacture is not, as such, patentable. Many new designs do not contribute in the least to the ornamentation of an article of manufacture. It was the intent of the framers of the design patent law to encourage ornamentation and beautification in manuiactured articles so as to increase their saleability and the enjoyment of their use by the public."

84. Jones Bros. Co. v. Underkoffler, 16 F. Supp. 729 (Ar. D. Pa. 1936), 6 Gro. WAsa. L. Rev. 135.

85. The court here quoted WeIL. Asrericin Copyrigrt LAN (1917) 227, for the proposition that certain designs are both copyrightable and patentable; accord, Louis De Jonge \& Co. v. Breuker \& Kessler Co., 182 Fed. 150 (E. D. Pa. 1910). 
This doctrine leads to the following practical effects: if the print or label is not only used "in connection" with an article of manufacture, but is an article in itself, or an ornamental part thereof, it should not be copyrighted as a print but protected as a design patent - provided always there exists a sufficient minimum of inventive genius and novelty to satisfy the Design Patent Act. If, on the other hand, the print at the time of the application is neither an article in itself nor made a physical part thereof (although perhaps designed to be so incorporated), it may come within that class of goods which, according to the Underkoffer case, qualify under either the Design Patent or Print and Label Law. Finally, if the print is for all practical purposes an industrial design, but lacks the required "inventive genius" or "novelty," it may not be registrable under either statute. ${ }^{80}$

\section{The Hybrid Under New Administration}

The Trade-Mark Division of the Patent Office, in following the Print and Label Law, has faithfully registered prints and labels "in conformity with the regulations provided by law as to copyright of prints." As a matter of fact, many of the more important provisions of the Copyright Act of 1909 were incorporated verbatim in the Patent Office rules concerning prints and labels. ${ }^{87}$ Most of these provisions - as, for instance, Section 8 dealing with alien applicants, Section 9 dealing with publication, or Section 18 dealing with copyright notice ${ }^{88}$ - are fundamentally

86. It is also conceivable that the print submitted for registration may fall into the category of utility patents-as where, for example, it embodies a new technical or mechanical device for office stationery or other business purposes. Much more frequent, of course, are those cases where the print was held not to be "used in connection with an article" on the ground that it constituted a print belonging to the fine arts and was, therefore, copyrightable as such. Thus it was held in Stecher Lith. Co. v. Dunston Lith. Co., 233 Fed. 601 (W. D. N. Y. 1916) that a "Chromo" or "Chromo-Lithograph" does not come within the scope of the Print and Label Law, so that a "Chromo", even if it has reference to an article of manufacture rather than to the fine arts, may be protected in the Copyright Office. Dixie Vortex Co. v. Lily-Tulip Cup Corp., 19 F. Supp. 511 (E. D. N. Y. 1937) decided that registration in the Copyright Office of a print which should have been registered in the Patent Office under the Print and Label Law was invalid, on the ground that the print there involved had no connection with the fine arts but was used exclusively for a commercial article (paper cup).

87. The following sections of the Copyright Act are enumerated in the rules: $\$ \S 7$, $8,9,18,23,24,42,43,46$ and 62 .

88. A dramatic illustration of the existing confusion is found in cases involving the requirement of $\S 18$ of the Copyright Act that there be pttblication of the print or label with copyright notice before the certificate is actually issued. This is diametrically op* posed to the well established principle of trade-mark law that it is a fraud upon the public to use the words "Reg. U. S. Patent Office" before a certificate of registration has been granted. In many instances, courts have refused to protect a trade-mark owner who attached such notice before the date of obtaining the certificate. See DERENDERG, TrAdEMark Protection and Unfair Trading (1936) 674. For similar holdings on related 
different from the procedural requirements for trade-mark registration. In administering these Sections, the Patent Office has functioned as "Copyright Office" rather than as "Trade-Miark Division." In this respect, therefore, the change in administration will hardly be noticed, although it may have the salutary effect of dispelling some of the present confusion concerning the formal requisites for the protection of prints and labels. ${ }^{83}$

It cannot be expected, nor would it be desirable, that the Copyright Office administer the registration of prints and labels so as to abrogate or disregard established principles of trade-mark or design patent law. Nothing which otherwise serves the function of a trade-mark or design patent should be protected under the guise of a label registration, if for some technical reason trade-mark registration or a design patent cannot be obtained.

It is to be hoped, on the other hand, that the Copyright Office will free itself from those restrictions which we have called "trade-mark" aspects and which to a large extent were read into the Print and Label Law by the Patent Office. Principles of affixation, descriptiveness and similar limitations should be ignored by the Copyright Office as having no place in the administration of the Copyright Act.

In any event, the transfer of jurisdiction and even the necessary adaptation of the existing "commercial" requisites for the registration of prints and labels to the standards and rules of the Copyright Office will accomplish little unless accompanied by a revision of prior concepts by the Copyright Office. Since commercial prints and labels are now accepted as copyrightable works in the Library of Congress, they should be treated with as much respect as works connected with the fine arts, provided they evidence the minimum amount of "intrinsic merit" which the Supreme Court in the Bleistein case held could exist even in a circus poster.

subject-matters see Four Roses Prod. Co. v. Small Grain Dist. \& Drug Co., 29 F. (2:1) 959 (App. D. C. 1928); Gillette Safety Razor Co. v. Standard Safety Razor C0., 25 T. M. Rep. 629 (C. P. 1935). It is indeed bewildering for the registrant of a label in the Patent Office to realize that a prior use of the statutory copyright notice before the issuance of the certificate is not only no fraud upon the public but a mandatory requirement for obtaining registration. All the more, if it is recalled that at one time the Commissioner of Patents stated in Ex parte Mioodie, 28 O. G. Pat. Off. 1271 (C. P. 18St), that "trade-marks and labels are so intimately connected that confusion might arise where they are supervised by separate and independent officials." Cf. Ex fartc James MIurphy, 27 T. M. Rep. 355 (C. P. 1937).

89. In a circular sent out in support of H. R. Bill 153, 76th Cong., 1st Sess., which subsequently became the law of June 31, 1939, it was said:

"Almost daily, the Copyright Office receives applieations for registration which it must return because the subject matter of the copyright comes within the 1874 law. Thousands of copyright labels are registered in the Patent Office under this 1874 law under the misapprehension that such registration protects the trade-marks appearing on the labels." 
It is clear, however, that the ultimate solution of the problem of divesting commercial prints and labels of their hybrid character will not be attained merely by a shift of jurisdiction or a new procedure within the Copyright Office. The basic problem, if incapable of solution by the legislator, must at least be met by recognition of its existence by the marketing expert and his counsel, and by subsequent reduction of the print or label into its protectable elements with appropriate registry for each, or for the most predominant, of them.

That the Copyright Office issues certificates of registration without examining the intrinsic artistic or literary merits of the print or label should not blind the applicant to the dangers of registering something which obviously fails to satisfy even the minimum standards of copyrightability. There should be no room in our copyright system for a "cy-pres" registration of business devices, which more properly belong within the realm of trade-marks or patents even though they lack some of the technical requirements of the latter. Wherever it appears that what the applicant really seeks and needs is protection of a slogan, trademark, trade-name or a mere advertising idea - a protection that copyright registration cannot give - he should be discouraged from even attempting to secure a copyright. ${ }^{20}$

It may be natural for a lawyer to accede to the request for immediate registration and to proceed to place the device on some registry in the Copyright Office without first analyzing the nature of the material and the type of protection it may require. Perhaps the interest of many a client would, however, be better served if no copyright registration at all were sought for a commercial print or label. The advertiser would then at least know where he lacks the protection of the law, and might thus avoid needless expenditures and subsequent disappointment.

90. The most recent federal decision, Jackson Pub. Co. v. Quickslip Co., Inc., 45 U. S. P. Q. 6 (C. C. A. 2d, 1940) corroborates the view here expressed and illustrates the disappointment which the copyright owner is bound to experience where his application is made without proper analysis of the objects sought to be protected. 